\title{
THE ROLE OF VILLAGE-OWNED ENTERPRISES (BUMDES) TO RURAL DEVELOPMENT: A COMPARATIVE INSTITUTIONAL ANALYSIS
}

\author{
Penulis: \\ I Gede Agus Ariutama ${ }^{1}$ \\ igedeagus@pknstan.ac.id \\ Acwin Hendra Saputra ${ }^{2}$ \\ acwin@pknstan.ac.id \\ Renny Sukmono 3 \\ rhey.sukmo@gmail.com
}

\begin{abstract}
Abstrak
Intervensi pemerintah untuk pembangunan desa dilakukan dengan berbagai kebijakan. Pembentukan BUMDes adalah salah satu upaya pemerintah untuk mempercepat pembangunan pedesaan, memajukan ekonomi lokal, dan mengembangkan kemitraan desa dan/atau kemitraan dengan pihak ketiga. Studi ini mengeksploitasi kerangka comparative institutional analysis untuk menganalisis lebih lanjut bagaimana aspek kelembagaan dapat mempengaruhi penerapan BUMDes dalam pembangunan pedesaan. Aspek-aspek kelembagaan terkait penggunaan BUMDes untuk pembangunan pedesaan patut ditekankan karena akan digunakan sebagai landasan antara para aktor dalam bidang sosial tertentu (struktur) dalam berbagai bentuknya seperti aturan, norma, atau rutinitas tertentu, dan institusi sebagai bentuk otoritas untuk perilaku sosial organisasi desa. Selanjutnya, keberhasilan pelaksanaan BUMDes dalam pembangunan pedesaan juga dipengaruhi oleh bagaimana sistem pemangku kepentingan dalam mengelola aspek kelembagaan. Penelitian ini, dari sudut pandang comparative institutional analysis, menggarisbawahi: (1) kewenangan yang terbatas dari Kementerian Desa, Pembangunan Daerah Tertinggal dan Transmigrasi terkait pembangunan pedesaan menunjukkan bahwa Kementerian ini harus menetapkan pengaturan kelembagaan khusus dengan Kementerian Dalam Negeri dan Kementerian Koperasi dan UKM serta lembaga perbankan; (2) Pemerintah desa belum sepenuhnya memanfaatkan fleksibilitas pengaturan kelembagaannya untuk menggunakan BUMDes sebagai sumber pembangunan pedesaan; (3) ada ruang lingkup yang cukup besar untuk meningkatkan peran BUMDes dalam pembangunan pedesaan. Penelitian ini akan mengusulkan beberapa saran praktis sambil mempertimbangkan pengaturan kelembagaan yang ada.
\end{abstract}

Kata Kunci: Desa; BUMDes; Pembangunan Desa; Comparative Institutional Analysis

\section{INTRODUCTION}

The concern related to rural development in developing countries still implicates the issue of poverty alleviation (Prabowo, 2014). The village as the closest government institution to society is still often depicted as small, weak and underdeveloped. The fact that most of Indonesian population (56.86 \%) live in rural areas makes it difficult to alleviate people from poverty without concerning and involving the rural areas which currently consist of more than 70 thousand villages. A set of policy should focus and prioritize the improvement of livelihoods of the rural population. The concept of inclusiveness then emerges as a key policy to boost the number of independent villages (Eko, 2014; Todaro,

\footnotetext{
${ }^{1}$ Department of Financial Management, Politeknik Keuangan Negara STAN, Tangerang Selatan

2 Department of Financial Management, Politeknik Keuangan Negara STAN, Tangerang Selatan

${ }^{3}$ Department of Financial Management, Politeknik Keuangan Negara STAN, Tangerang Selatan
} 
Smith and Munandar, 2004). Innovation at the village level can be centered around Social, Financial and Production Infrastructure within the framework of Inclusive Development. President Jokowi apprehends the importance of rural development by setting the national development through villages as outlined in president's vision, Nawa Cita.

Indonesian government picks out Village-owned enterprises (BUMDes) as one of the solutions for enhancing rural development (Raharjo, Yudanto and Ariutama, 2017; Solekhan, 2014). The legal basis of BUMDes in Act Number 6 Year 2014 Chapter $X$ specifically from Article 87 to Article 90 mentioned that the village can establish and manage village-owned enterprises called BUMDes with the principles of brotherhood and mutual cooperation. Later the Ministry of Villages, Development of Underdeveloped Regions and Transmigration Regulation No. 4 Year 2015 was set as the technical implementation of BUMDes along with its the roles and function.

Article 1 letter 2 of Minister Regulation No.4/2015 states the objective of BUMDes, specifically: (1) improve the economy of the village; (2) optimize village assets for the benefit of the welfare of the village; (3) improve the efforts of the villagers to manage the economic potentials of their village; (4) develop cooperation plan between rural businesses and/or third parties; (5) create market opportunities and networks to meet the need of villagers for public services; (6) provide jobs; (7) improve the welfare of villagers through improvements of public services, economic growth and equal distribution of the village economy; (8) increase the income of the villagers and the village (Putra, 2015).

According to Sihabudin (2009), BUMDes as a rural economic institution is expected to be able to strengthen rural economy by: (1) service improvement in accordance with the necessities and characteristics of the society; (2) interaction of BUMDes with the other institution such as cooperation which has to be facilitated and protected by village or local government, especially the existence and the sustainability of BUMDes to be maintained; and (3) institutional rules of BUMDes which have to be consistent with the essence of village as a public legal entity to manage the local community.

Based on the above description, an interesting issue to examine further is how the position and role of BUMDes in rural development and whether BUMDes has been effective as one of the instruments of village development. More specifically, how the institutional aspects affect the position, role, and function of BUMDes. The institutional aspect referring to Scott (2005) is the existence of a social structure, such as schemes, rules, norms and routines, into authoritative forms for the occurrence of social behavior in organizations. This study uses a comparative institutional analysis framework as proposed by Cole (2013) to examine the various structures, policies, or rules relating to the implementation of BUMDes as one of the axes of village development. 


\section{LITERATURE REVIEW}

\section{A. Reform through Decentralization}

Law 22/1999 is the first legal basis for the Indonesia decentralization reform. Although not known as BUMDes at that time, article 108 of law 22/1999 encourages the establishment of institution or enterprise to manage their resource efficiently and autonomously. The reforms continue to roll until the passage of the law 32/2004 which clearly and unequivocally states the existence of BUMDes as a rural finance instrument even though still limited by village own needs and economic capacities. Furthermore, Government Regulation (PP) 72/2005 article 78 paragraph (1) states that "In order to increase villager's income, Village Government may (optional) establish village-owned enterprises in accordance with the needs and potential of the Village". This opportunity needs two basic prerequisites that is reliable entity as well as professional human resource to manage its village potential resources.

The law No. 6 Year 2014 functions as a basis for recognition of the village existence in the Indonesian Government System. The purpose of the policy which gives village a wider authority to organize, serve and take care of the interests of society is to realize social welfare with the best use of its own potential resources through its village-owned enterprise. Technical guidance further arranged in Ministerial Regulation No.4/2015.

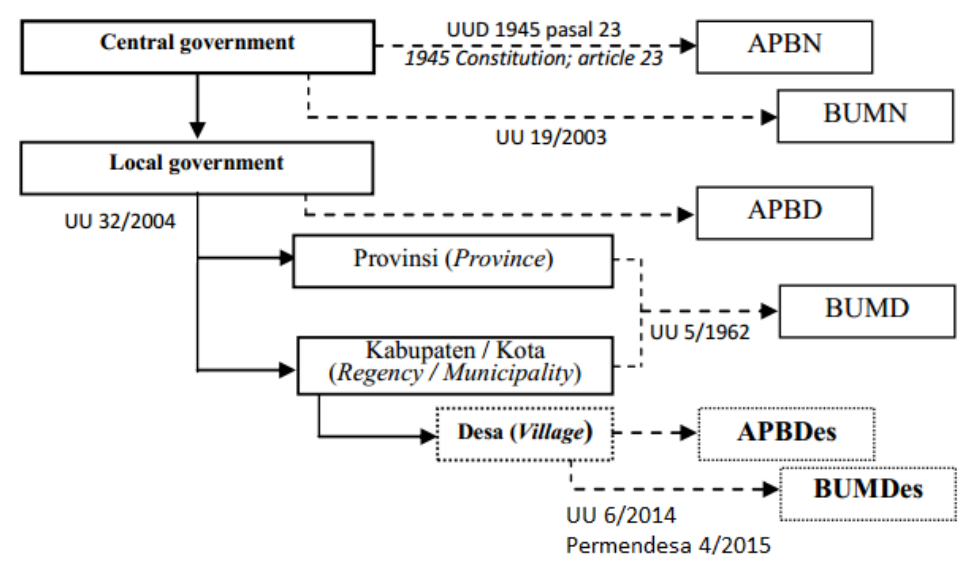

Fig. 1 Anatomy of Government of the Republic of Indonesia and State Own Arrangement

In addition, the existence of institutions BUMDes is directed to contribute to the improvement of village revenue sources (PADes), so the village can carry out the development and improvement of people's welfare more optimally (Ridlwan, 2014; Badriyadi, 2013). Based on the terms of the concept (according to Law [UU] and PP), the formation of BUMDes is to immediately realize the welfare of rural communities. However, in terms of implementation, there are still many areas and villages that do not have the initiative and motivation to develop the intended BUMDes. 


\section{B. Comparative Institutional Analysis}

The term institution is a term that has a variety of meanings, very dependent on the point of view and disciplines that use it. According to Cole (2013), it is explained that institutions are terms used (and given different meanings) by many disciplines, at least sociology, economics, law, and politics. Consequently, institutional analysis as an analytical tool will use the basic principles of the existence and function of an institution that is also used by these different disciplines. However, herein lies precisely the superiority of institutional analysis, the characteristic which tends to be multidisciplinary, so it can be used to look at a problem from different points of view. This approach is important to understand the socio-institutional aspects of using BUMDes as a village development instrument.

Comparative institutional analysis basically aims to find the most appropriate institutional arrangement to achieve the desired goals. This analysis does not emphasize the comparative analysis of institutions but rather determines which institutional boundaries will be selected and what criteria are used to assess those institutional limits and their arrangements to help achieve their objectives. This study deliberately selects comparative institutional analysis with the aim of explaining how the position and role of BUMDes in rural development. Therefore, the operational definition of comparative institutional analysis in this study, with reference to Cole (2013) is: an analysis to determine institutional arrangements to obtain a balanced condition within a particular area (BUMDes policy) that enables all perpetrators (central government, rural apparatus, banking, BUMDes and village society) to achieve their respective objectives.

\section{METHODS}

This study, according to Bowen (2009), uses a qualitative method with documentation study approach in the form of various legal provisions, and other system documentation related to the development and operation of village-owned enterprise in Indonesia. Documentation of the system in this context includes: organizational structure, related BUMDes/current policy structure, such as technical regulations related to BUMDes and other BUMDes related regulations. The data acquired will be analyzed to obtain the findings and conclusions of the study by using comparative institutional analysis framework. This paper will analyze the institutional aspects as defined in the operational definition by using various publicly available data from the documentation of BUMDes authority regulations, previous research results, and mass media (printed or online).

\section{DISCUSSION}


Referring to the operational definition of comparative institutional analysis in this study, this discussion will address: (1) the boundaries of the selected institutions; (2) the institutional arrangement that covers the role of BUMDes in the existing institutional arrangement system to the achievement of the objectives of each of the actors involved in the existing institutional environment.

The study finds that although the operational definition of rural development as an institution is the same, but it is the institutional arrangement that will affect the development and operation of BUMDes roles and functions in each village authority. Comparison of how central government authorities with village government authority's institutional arrangement in realizing village development is shown in table 1.

From Central Government policy making authority, there are three aspects to be discussed in this study. For BUMDes as the key instrument to village development, there are at least three main regulators directly involved, specifically Ministry of Villages, Underdeveloped Regions and Transmigration; Ministry of Internal Affairs (with its vertical government institution); and Ministry of Cooperatives and Small and Medium Enterprises. Furthermore, support of existing regulations will likely strengthen the existing institutional settings. Clarity of rules related to BUMDes legality establishment model and technical rules of the local government related to the operation of BUMDes are two substantial aspects required to be clarified regarding the arrangement of BUMDes. The last aspect related to central government is establishment legality of BUMDes. It is a big problem for the Financial Management Unit as embryonic BUMDes since Financial Management Unit is business activities engaged in the Business Savings and Loans (Sudaryana, 2016) and related to Banking regulation.

Table 1. Form of Institutional Arrangement of BUMDes

\begin{tabular}{|l|l|}
\hline $\begin{array}{c}\text { BUMDes related } \\
\text { policy-making } \\
\text { authority }\end{array}$ & \multicolumn{1}{c|}{ The form of Institutional Arrangement } \\
\hline $\begin{array}{l}\text { Central } \\
\text { Government }\end{array}$ & $\begin{array}{l}\text { - Three main regulators for operation of BUMDes (multi regulators): (1) } \\
\text { Ministry of Villages, Underdeveloped Regions and Transmigration; (2) } \\
\text { Ministry of Internal Affairs (with its vertical government institution); (3) } \\
\text { Ministry of Cooperatives and Small and Medium Enterprises. } \\
\text { - Two main issues related to existing institutional settings, namely clarity of } \\
\text { rules related to BUMDes legality establishment model and technical rules of } \\
\text { the local government related to the operation of BUMDes. } \\
\text { - The legality of the establishment for the Financial Management Unit as } \\
\text { embryonic BUMDes. }\end{array}$ \\
\hline $\begin{array}{l}\text { Village } \\
\text { Government }\end{array}$ & $\begin{array}{l}\text { The role and existence of BUMDes at the village level, i.e. the relation of the } \\
\text { board of BUMDes with the Village Government, and the professional aspect } \\
\text { in the management of BUMDes. }\end{array}$ \\
& $\begin{array}{l}\text { The need for further related studies about the form of the village partnerships } \\
\text { and/or third party's partnerships. }\end{array}$ \\
& $\begin{array}{l}\text { The organization of BUMDes as a social business organization requires a } \\
\text { strong commitment especially at the village level, especially in terms of } \\
\text { "gotong royong" and volunteerism. }\end{array}$ \\
\hline
\end{tabular}


Regarding village government, three issues are further analyzed, specially role and existence of BUMDes, form of village partnership, and social business organization. First, comprehensibility of two institutional arrangement needs related to the role and existence of BUMDes at the village level should be reviewed, i.e. the relation of the board of BUMDes with the Village Government, and the professional aspect in the management of BUMDes. Second, further related studies about the form of the village partnerships and/or third party's partnerships should be encouraged to improve the professionalism of BUMDes management (Susilo dan Purnamasari, 2016). The last one, the organization of BUMDes as a social business organization requires a strong commitment especially at the village level, especially in terms of "gotong royong" and volunteerism. If the BUMDes is directed into a professional business organization, it will result in a transactional pattern of relationships and a low sense of belonging to the social capital that forms the BUMDes. Furthermore, it will be more complicated if the initial capital of BUMDes comes from the Banking system. Social capital which is important to create competitive business unit means norms and networks enabling people to cooperate by emphasizing synergy, networks, communitarian and institutional to promote economic and social growth (Woolcock, 1998). Social capital in the forms of shared values, and regulations expressed in personal relationship, trust and common sense about collective responsibility are required to generate competitive advantage of the BUMDes.

\section{CONCLUSION}

The use of BUMDes as one of the instruments of village development is highly dependent on the institutional arrangement either by the central government or village. The practical suggestions for the selection of institutional arrangements on BUMDes are: (1) simplification of regulations and policy makers for BUMDes; (2) clarification of the form of BUMDes legal entity in order not to be biased; (3) clarity on the aspect of legality must be emphasized in order to synergize with banking regulations; (4) a clear pattern of relations between the board of BUMDes and the Village Government; (5) advancement of professionalism in the management of BUMDes; (6) necessity to develop commitment and a strong sense of ownership of BUMDes within the village community.

\section{ACKNOWLEDGEMENT}

This research was supported by Research and Community Service Politeknik Keuangan Negara STAN. 


\section{REFERENCES}

Badriyadi. "Pengelolaan dana pinjaman di desa sungai raya." Publika Vol 2 No 1. (2013).

Bowen, Glenn A. "Document analysis as a qualitative research method." Qualitative research journal 9.2 (2009): 27-40.

Cole, Daniel H. "The varieties of comparative institutional analysis." Wis. L. Rev. (2013): 383-409.

Eko, Sutoro. "Desa Membangun Indonesia." FPPD. Yogyakarta (2014).

Prabowo, T. Handono Eko. "Developing Management System BUMDes (Village-Owned Enterprise) For Sustainable Poverty Alleviation Model." World Applied Sciences Journal 30, (2014): 19-26.

Putra, Anom Surya. "Badan Usaha Milik Desa Spirit Usaha Kolektif Desa." Kementerian Desa, Pembangunan Daerah Tertinggal, dan Transmigrasi. Jakarta 2015 (2015).

Raharjo, Taufik, Yudanto, Ambang Aries, and Ariutama, I Gede Agus. "Asistensi Pendirian Badan Usaha Milik Desa Cibogo, Kecamatan Cisauk, Kabupaten Tangerang." Proceeding of Community Development 1 (2017): 350-355.

Ridlwan, Zulkarnain. "Urgensi Badan Usaha Milik Desa(BUMDES) dalam Pembangun Perekonomian Desa." Jurnal IImu Hukum 8.3 (2014): 424-440.

Scott, W. Richard. "Institutional theory: Contributing to a theoretical research program." Great minds in management: The process of theory development 37 (2005): 460-484.

Sihabudin. "Legal Entity form of village-owned enterprises (BUMDes) Potential-Based Village Economy." Journal of Social Sciences (Social Sciences), 21 (1), (2009): 33-41.

Solekhan, Moch. Penyelenggaraan pemerintahan desa berbasis partisipasi masyarakat. Setara Press, 2014.

Sudaryana, Bambang. 2016. "The Model of Development Policy Implementation of Village Owned Enterprises in Indonesia." Advances in Social Science, Education dan Humanities Research (ASSEHR), Vol. 81. Atlantis Press. (2016). doi:10.2991/icosop$\underline{16.2017 .3}$

Susilo, Budi and Purnamasari, Nurul. "Potensi Permasalahan yang Dihadapi Badan Usaha Milik Desa (BUMDes): Telaah Kajian Potensi dan Permasalahan pada BUMDes Hanyukupi Ponjong dan BUMDes Sejahtera Bleberan di Kabupaten Gunungkidul." (2016). Accessed August 14, 2018. http://www.keuangandesa.com/wpcontent/uploads/2016/05/potensi-dan-permasalahan-yang-dihadapi-bum-desa.pdf

Todaro, Michael P., Smith, Stephen C., and Munandar, haris. Pembangungan ekonomi di dunia ketiga $8^{\text {th }}$ edition. Erlangga. Jakarta (2004).

Woolcock, Michael. "Social capital and economic development: Toward a theoretical synthesis and policy framework." Theory and society 27.2 (1998): 151-208. 